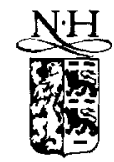

\title{
Detecting long-run abnormal stock returns: The empirical power and specification of test statistics
}

\author{
Brad M. Barber*, John D. Lyon \\ Graduate School of Management, University of California- Davis, Datis, CA 956I6, USA
}

(Received November 1995; final version July 1996)

\begin{abstract}
We analyze the empirical power and specification of test statistics in event studies designed to detect long-run (one- to five-year) abnormal stock returns. We document that test statistics based on abnormal returns calculated using a reference portfolio, such as a market index, are misspecified (empirical rejection rates exceed theoretical rejection rates) and identify three reasons for this misspecification. We correct for the three identified sources of misspecification by matching sample firms to control firms of similar sizes and book-to-market ratios. This control firm approach yields well-specified test statistics in virtually all sampling situations considered.
\end{abstract}

Key words: Event studies; Firm size; Book-to-market ratios JEL classification: $\mathrm{G} 12 ; \mathrm{G} 14$

\section{Introduction}

Many recent studies in financial economics analyze the long-run behavior of stock returns following major corporate events or decisions, such as dividend initiation, stock splits, acquisitions, or security offerings. In these studies, the post-event return performance of sample firms is tracked for a period of time following the event. There is considerable variation in the measures of abnormal returns and the statistical tests that empirical researchers use to detect

\footnotetext{
* Corresponding author.

Peter Hall, Chih-Ling Tsai, and David Rocke provided valuable insights on the statistical issued involved in this paper. We are grateful for the comments of Anup Agrawal, Sanjai Bhagat, Peter Clark. Masako Darrough, Eugene Fama (the referee), Paul Griffin, Prem Jain, Kathy Kahle, S.P. Kothari, Michael Maher, Wayne Mikkelson, Mark Nelson, Jay Ritter, Bill Schwert (the editor), Siew Hong Teoh, Russ Wermers, and seminar participants at Michigan. Oregon, and UC-Davis. All errors are our own.
} 
long-run abnormal stock returns. While Brown and Warner (1980, 1985), Dyckman, Philbrick, Stephan, and Ricks (1984), and Campbell and Wasley (1993) all document the empirical specification and power of test statistics designed to detect abnormal stock returns, these studies focus on the characteristics of abnormal returns measured on a particular day or, at the most, cumulated over several months. In contrast, our research documents the empirical power and specification of test statistics designed to detect long-run abnormal stock returns. Our analysis focuses on annual, three-year, and five-year returns. We argue that many of the common methods used to calculate long-run abnormal stock returns are conceptually flawed and/or lead to biased test statistics.

We consider two main issues in tests designed to detect long-run abnormal stock returns. First, we consider the calculation of abnormal returns. We argue that researchers should calculate abnormal returns as the simple buy-and-hold return on a sample firm less the simple buy-and-hold return on a reference portfolio or control firm. We document the biases that are induced by summing daily or monthly abnormal returns (referred to in the financial economics literature as cumulative abnormal returns). Second, we empirically evaluate the performance of three approaches for developing a benchmark for long-run stock returns. The first approach employs the return on a reference portfolio to calculate abnormal returns. The second approach matches sample firms to control firms on specified firm characteristics. The third approach is an application of the three-factor model of Fama and French (1993). We document the empirical power and specification of test statistics designed to detect long-run abnormal stock returns based on different methods of calculating long-run abnormal returns and different approaches for developing a long-run return benchmark. Our analysis focuses on the annual, three-year, and five-year returns of firms listed on the New York, American, and NASDAQ exchanges with available data on the monthly return files maintained by the Center for Research in Security Prices (CRSP) from July 1963 through December 1994.

Our empirical results yield two insights. First, we document that using reference portfolios, such as an equally weighted market index or size decile portfolios, to calculate long-run abnormal returns is problematic. In general, abnormal returns calculated using reference portfolios yield test statistics that are misspecificed (empirical rejection rates exceed theoretical rejection rates). In Section 2, we identify and discuss in detail three reasons for the observed biases in test statistics. In brief, these three biases include:

- new listing bias, which arises because in event studies of long-run abnormal returns, sampled firms generally have a long post-event history of returns, while firms that constitute the index (or reference portfolio) typically include new firms that begin trading subsequent to the event month;

- rebalancing bias, which arises because the compound returns of a reference portfolio, such as an equally weighted market index, are typically 
calculated assuming periodic (generally monthly) rebalancing, while the rcturns of sample firms are compounded without rebalancing; and

- skewness bias, which arises because long-run abnormal returns are positively skewed.

We find that cumulative abnormal returns (summed monthly abnormal returns) yield positively biased test statistics, while buy-and-hold abnormal returns (the compound return on a sample firm less the compound return on a reference portfolio) yield negatively biased test statistics. These apparently contradictory results occur because of the differential impact of the new listing, rebalancing, and skewness biases on cumulative abnormal returns and buy-and-hold abnormal returns.

The second insight to emerge from our analysis is the efficacy of a control firm approach for detecting long-run abnormal stock returns. We document that matching sample firms to control firms of similar sizes and book-to-market ratios yields test statistics that are well specified in virtually all sampling situations that we consider. This control firm approach yields well-specified test statistics because it alleviates the new listing, rebalancing, and skewness biases.

Kothari and Warner (1996) also analyze the properties of long-run abnormal returns. Both our work and that of Kothari and Warner highlight the problems associated with calculating long-run abnormal returns using either a reference portfolio approach (which is discussed in detail in our work) or an application of an asset pricing model (which is discussed in detail by Kothari and Warner). However, we show that the control firm approach to calculating abnormal returns is robust to virtually all sampling situations that we consider. Though we highlight important differences between the two studies in this analysis, Barber and Lyon (1996a) thoroughly document all of the differences and their implications.

The remainder of this paper is organized as follows. In Section 2, we discuss sources of bias in the calculation of long-run abnormal returns. We discuss the return data, the construction of reference portfolios, and the application of the Fama-French three-factor model in Section 3. The calculation of cumulative abnormal returns, buy-and-hold abnormal returns, our empirical methods, and the statistical tests that we use are defined in Section 4. Results are presented in Section 5. We discuss tests of median abnormal returns in Section 6. We close the paper in Section 7 with specific recommendations about the calculation of long-run abnormal returns.

\section{The calculation of long-run abnormal returns}

The convention in much of the research that analyzes abnormal returns has been to sum either daily or monthly abnormal returns over time. Define $R_{l t}$ as the month $t$ simple return on a sample firm, $\mathrm{E}\left(R_{i t}\right)$ as the month $t$ expected return 
for the sample firm, and $A R_{i t}=R_{i t}-\mathrm{E}\left(R_{i t}\right)$ as the abnormal return in month $t$. Cumulating across $\tau$ periods yields a cumulative abnormal return (CAR):

$$
C A R_{i \tau}=\sum_{t=1}^{\tau} A R_{i t} \text {. }
$$

In contrast, the return on a buy-and-hold investment in the sample firm less the return on a buy-and-hold investment in an asset/portfolio with an appropriate expected return (BHAR) is

$$
B H A R_{i \tau}=\prod_{t=1}^{\tau}\left[1+R_{i t}\right]-\prod_{t=1}^{\tau}\left[1+\mathrm{E}\left(R_{i t}\right)\right] .
$$

In this section, we discuss issues that lead to biases in the calculation of test statistics designed to detect long-run abnormal stock returns. Later, we consider several alternative methods of arriving at an expected return for a sample firm. However, in this section, for purposes of discussion, we consider the return on an equally weighted market index $\left(R_{m t}\right)$ as the expected return for each security. When we present our empirical results, we consider how the various biases affect the calculation of long-run abnormal returns when alternative expectation models are employed.

\subsection{Cumulative abnormal returns (CARs)}

Ritter (1991) was among the first to argue that CARs and BHARs can be used to answer different questions. Consider the case of a 12-month CAR and an annual BHAR. Dividing the 12-month CAR by 12 yields a mean monthly abnormal return. Thus, a test of the null hypothesis that the 12-month CAR is zero is equivalent to a test of the null hypothesis that the mean monthly abnormal return of sample firms during the event year is equal to zero; it is not a test of the null hypothesis than the mean annual abnormal return is equal to zero. To test the latter hypothesis, a researcher needs to use the annual BHAR.

The difference between these two hypothesis tests can be understood by considering the difference between CARs and BHARs. We randomly sample 10,000 observations between July 1963 and December 1993 from the CRSP NASDAQ and NYSE/AMEX monthly return files. (The data set used in this research is discussed in detail in Section 3.) We calculate a 12-month CAR and an annual BHAR using the CRSP NYSE/AMEX/NASDAQ equally weighted market index for each of the 10,000 observations. These 10,000 observations are then ranked into 100 portfolios of 100 securities each on the basis of their annual BHAR. This ranking creates the maximum spread in the annual BHAR. For each of the 100 portfolios, we calculate the mean difference between the cumulative and buy-and-hold abnormal returns $\left(C A R_{i \tau}-B H A R_{i \tau}\right)$. In Fig. 1, we plot this mean 


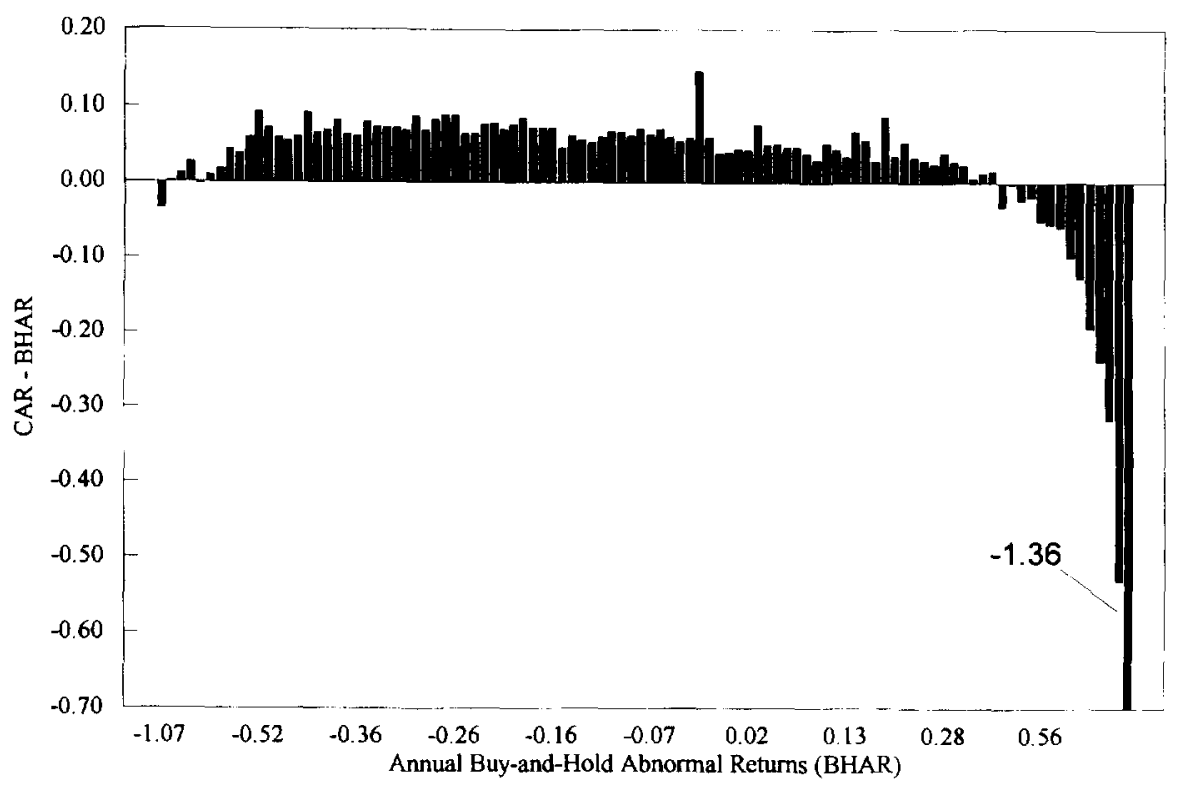

Fig. 1. The difference between 12-month cumulative abnormal returns (CARs) and annual buyand-hold-abnormal returns (BHARs) plotted against annual BHAR for 100 portfolios formed on the basis of annual BHAR.

For a random sample of 10,000 observations, an annual BHAR and a 12-month CAR are calculated for each observation using an equally weighted market index. The observations are ranked by BHARs, then 100 portfolios of 100 securities are created based on the BHAR ranking. The figure plots the mean difference between the 12-month CAR and annual BHAR against the annual BHAR

difference against the mean annual BHAR for each of the 100 portolios. The figure reveals predictable differences between CARs and BHARs. When the annual BHAR is less than approximately $13 \%$, the CAR is approximately $5 \%$ greater than the BHAR, on average. The difference between the CARs and BHARs decreases as the annual BHAR approaches $28 \%$. As the annual BHAR increases beyond $28 \%$, the CARs are dramatically less than the annual BHAR.

The differences between the CARs and BHARs result from the effect of monthly compounding; CARs ignore compounding, while BHARs include the effect of compounding. If individual security returns are more volatile than the returns on the market index, it can be shown that CARs will be greater than BHARs if the BHAR is less than or equal to zero. As the annual BHAR becomes increasingly positive, the difference between the CAR and BHAR will approach zero and eventually become negative. These results are empirically verified in Fig. 1.

To understand the implication of these differences, consider a sample of firms that all have an annual BHAR close to zero. On average, Fig. 1 reveals that this 
sample has a mean CAR of approximately $5 \%$, so that sample firms have mean monthly abnormal returns of approximately $0.42 \%$ (5\%/12 months). However, since individual security returns are more volatile on average than the returns on the reference portfolio, this mean monthly abnormal return does not translate into a positive mean annual abnormal return. A simple example illustrates the intuition of this result. Consider a sample firm and reference portfolio with consecutive monthly returns of $(0 \%, 44 \%)$ and $(20 \%, 20 \%)$, respectively. The two-month CAR is $4 \%$, while the two-month BHAR is zero.

Assume that CARs and BHARs both have a population mean of zero. (Later in this section, we will discuss reasons why they do not have a zero population mean.) Though particular sample means for both CARs and BHARs are unbiased with respect to zero, CARs are biased estimators of BHARs. We draw a random sample of 200,000 observations and calculate a 12-month CAR and an annual BHAR using an equally weighted market index. When we estimate the following regression:

$$
B H A R_{i, 12}=\lambda_{0}+\lambda_{1} C A R_{i, 12}+\varepsilon_{i}
$$

for this sample, the resulting intercept and slope coefficients are $\hat{\lambda}_{0}=-0.013$ $(0.0007)$ and $\lambda_{1}=1.041(0.0014)$, where the numbers in parentheses are the coefficient standard errors. If unbiased, the intercept and slope coefficients would be zero and one, but both the intercept and slope coefficients are significantly different from zero and one, respectively. The adjusted $R^{2}$ of the regression is $77.6 \%$.

In sum, cumulative abnormal returns are a biased predictor of long-run buyand-hold abnormal returns. Consequently, on conceptual grounds, we favor the use of buy-and-hold abnormal returns in tests designed to detect long-run abnormal stock returns. We refer to this problem as measurement bias and document the magnitude of this bias at the close of Section 5 .

Moreover, in studies of long-run abnormal returns, researchers are required to identify an initial event month for each sample firm. Yet many new firms begin trading subsequent to this initial event month. These newly listed firms become part of the market index against which the sample firm's performance is measured. The inclusion of these newly listed firms in the market index and their exclusion from the potential sample in the initial event month can cause the population mean CAR to depart from zero. The population mean CAR will be positive if newly listed firms underperform market averages, while it will be negative if newly listed firms outperform market averages. Ritter (1991) documents that firms that go public underperform an equally weighted market index. It is likely that these firms are a significant portion of newly listed firms. Consequently, over long horizons, we anticipate that the population mean for cumulative abnormal returns will be positively biased. We refer to this bias as the new listing bias. 


\subsection{Buy-and-hold abnormal returns (BHARs)}

As previously discussed, we favor the use of buy-and-hold abnormal returns to cumulative abnormal returns on conceptual grounds. However, the use of buyand-hold abnormal returns suffers from three drawbacks.

As with cumulative abnormal returns, buy-and-hold abnormal returns are subject to the new listing bias. Since newly listed firms underperform market averages (Ritter, 1991), we anticipate that the new listing bias will lead to a positive bias in the population mean of long-run buy-and-hold abnormal returns. In addition, long-run buy-and-hold abnormal returns are severely positively skewed. It is common to observe a sample firm with an annual return in excess of $100 \%$, but uncommon to observe a return on the market index in excess of $100 \%$. Since abnormal returns are calculated as the sample firm return less the market return, the abnormal returns are positively skewed.

For example, in the random sample of 200,000 annual buy-and-hold abnormal returns previously described, the mean buy-and-hold abnormal return is $-0.48 \%$, while the median is $-7.23 \%$. Furthermore, in this sample only $42 \%$ of all firms have positive buy-and-hold abnormal returns. This positive skewness is less pronounced in CARs because the monthly returns of sample firms are summed rather than compounded. In the random sample of 200,000 12-month cumulative abnormal returns, the mean cumulative abnormal return is $0.82 \%$, while the median is $-0.99 \%$. Approximately $49 \%$ of all firms have positive 12 -month cumulative abnormal returns, though as previously discussed a positive 12-month CAR is not sufficient evidence to conclude that a firm has beaten the market.

Consider a test statistic calculated as the mean buy-and-hold abnormal return of sample firms divided by the cross-sectional standard deviation of sample firms. The positive skewness of buy-and-hold abnormal returns leads to a negative bias in test statistics calculated in this manner. In short, the negative bias arises from the positive correlation between sample means and sample standard deviations in positively skewed distributions. The intuition of this result is as follows. Consider a particular sample with a positive sample mean. Conditional on observing a positive sample mean, it is more likely that this sample contains one of the extreme positive observations. The extreme positive observation will lead to an inflated estimate of the true standard deviation, resulting from the fact that the extreme observations are overrepresented in the sample relative to the underlying distribution. The inflated estimate of the cross-sectional standard deviation will lead to a downwardly biased test statistic, conditional on observing a positive sample mean.

Alternatively, consider a particular sample with a negative mean. It is likely that this sample underrepresents the extreme positive observations. Since the extreme positive observations are underrepresented in the sample, the estimated cross-sectional standard deviation will be deflated relative to the true standard deviation. The deflated estimate of the cross-sectional standard deviation will lead 
to a positively biased test statistic (in absolute value), conditional on observing a negative sample mean.

To illustrate the impact of the correlation between sample means and sample standard deviations on calculated test statistics, we conduct the following experiment. We randomly draw 1,000 samples of 50 observations from a $\chi^{2}$ distribution with one degree of freedom. We choose the $\chi^{2}$ distribution for two reasons. First, we know with certainty that the population mean for this distribution is one. ${ }^{1}$ Second, like the distribution of buy-and-hold abnormal returns, the $\chi^{2}$ distribution is positively skewed with a skewness measure of 2.83 . In the 1,000 samples, we reject the null hypothesis that the sample mean is equal to one (the population mean) at the $5 \%$ theoretical significance level in favor of the alternative hypothesis that the sample mean is significantly less than one in $6.6 \%$ of all samples and in favor of the alternative hypothesis that the sample mean is significantly greater than one in no samples. We refer to this as the skewness bias.

Finally, when buy-and-hold abnormal returns are calculated using an equally weighted market index, the long-run return on the index is compounded assuming monthly rebalancing of all securities constituting the index. To maintain equal weighting of all securities in the index, securities that have beaten market averages are sold, while those that have lagged market averages are purchased. This rebalancing will lead to a bias in the population mean for buy-and-hold abnormal returns if the consecutive monthly returns for individual securities are correlated. As it turns out, this monthly rebalancing leads to an inflated return on the market index and a negative bias in buy-and-hold abnormal returns.

For all NYSE/AMEX/NASDAQ securities from July 1963 through December 1994 Table 1 presents the percentage mean monthly returns in month $t$ for ten portfolios formed on the basis of the mean monthly return in month $t-1$. The last column of this table reveals that firms with high (low) returns in month $t-1$ experience low (high) returns in month $t$. Thus, the monthly rebalancing implicitly assumed when compounding the equally weighted market return leads to the purchase of firms that subsequently perform well (poor performers in month $t-1$ ) and the sale of firms that subsequently perform poorly (good performers in month $t-1$ ). Consequently, relative to sample firms, the long-run return on the equally weighted market index is inflated, leading to a negative bias in the population mean for long-run buy-and-hold abnormal returns. We refer to this bias as the rebalancing bias. Canina, Michaely, Thaler, and Womack (1996) document that the magnitude of the rebalancing bias is more pronounced when one uses daily, rather than monthly, returns. (The rebalancing bias does not affect the

\footnotetext{
I Note that running this experiment on long-run buy-and-hold abnormal returns is problematic because the true population mean departs from zero for reasons discussed throughout this section. Consequently, such an experiment is unable to isolate the impact of positive skewness on test statistics. By analyzing a distribution for which we know the true population mean, we are able to isolate the problem of positive skewness.
} 
Table 1

Percentage arithmetic mean monthly returns in months $t$ and $t-1$ of NYSE/AMEX/NASDAQ Firms sorted into deciles on the basis of monthly return in $t-1$

In each month from July 1963 through December 1994 all firm-month returns are sorted into deciles based on the return in month $t-1$. The mean return for firms in each decile is then calculated in month $t$.

\begin{tabular}{lcc}
\hline $\begin{array}{l}\text { Month } t-1 \\
\text { return decile }\end{array}$ & $\begin{array}{l}(\%) \text { mean } \\
\text { return in } t-1\end{array}$ & $\begin{array}{l}(\%) \text { mean } \\
\text { return in } t\end{array}$ \\
\hline 1 (Low) & -20.50 & 3.26 \\
2 & -10.08 & 1.54 \\
3 & -6.06 & 1.36 \\
4 & -3.30 & 1.31 \\
5 & -1.03 & 1.31 \\
6 & 1.20 & 1.18 \\
7 & 3.67 & 1.12 \\
8 & 6.80 & 0.99 \\
9 & 11.74 & 0.74 \\
10 (High) & 30.00 & -0.15 \\
\hline
\end{tabular}

calculation of cumulative abnormal returns, since the monthly returns of sample firms and the index are both summed rather than compounded.)

These return reversals do not necessarily indicate a profitable trading strategy. Assume that firms with high (low) returns in month $t-1$ are more likely to have a closing transaction at the posted ask (bid) price, but are equally likely to have a closing transaction at the bid or ask price in period $t$. This bid-ask bounce can at least partially explain the return reversals that we document. Blume and Stambaugh (1983) analyze the effect of the bid-ask bounce on the small firm premium. Conrad and Kaul (1993) and Ball, Kothari, and Wasley (1995) analyze the implications for contrarian strategies. Roll (1983) also documents that even absent the bid-ask bounce, nonsynchronous trading can lead to negative serial dependence in returns.

In summary, cumulative abnormal returns are subject to a measurement bias, a new listing bias, and a skewness bias, although we document that the skewness bias is less severe for cumulative abnormal returns than for buy-and-hold abnormal returns. Buy-and-hold abnormal returns are subject to a new listing bias, a skewness bias, and a rebalancing bias.

\subsection{Continuously compounded vs. simple returns}

The empirical analysis in this paper is based on returns calculated as the change in price plus dividends scaled by the beginning-of-period price, which we refer to as the simple return. Continuously compounded returns yield inherently negatively 
biased estimates of long-run abnormal returns. The negative bias occurs because there is considerable cross-sectional variation in the returns of common stocks.

Consider a market with two securities, A and B. Securities A and B earn simple annual returns of $20 \%$ and $10 \%$, respectively. An equally weighted index of the two securities earns a simple annual return of $15 \%$. The buy-andhold abnormal returns for $\mathrm{A}$ and $\mathrm{B}$ are $+5 \%$ and $-5 \%$, respectively, and the mean abnormal return for the two securities is zero. In contrast, the continuously compounded returns for securities $\mathrm{A}$ and $\mathrm{B}$ are $18.2 \%$ and $9.5 \%$, while the continuously compounded return on an equally weighted index is $14.0 \%$. Using continuously compounded returns to calculate abnormal returns yields an abnormal return of $+4.2 \%$ for $\mathrm{A}$ and $-4.5 \%$ for $\mathrm{B}$. The mean continuously compounded abnormal return for the two securities is $-0.3 \%$. In fact, only when all securities that constitute an index have equal simple returns will the continuously compounded abnormal returns across all securities sum to zero. Otherwise, the mean continuously compounded abnormal return will be negative. For this reason, we object to the use of continously compounded returns for analyzing long-run return performance.

\section{The returns data}

In this section, we describe the data set that we use in our empirical analysis and discuss alternatives to the use of an equally weighted market index for calculating long-run abnormal stock returns.

\subsection{Defining the population}

Our analysis begins with all NYSE/AMEX/NASDAQ firms with available data on the monthly return files created by CRSP. Between July 1963 and December 1994 there are 1,798,509 firm-month returns. We begin in July 1963 because we require Compustat data on the book value of common equity, which is not generally available prior to 1962. Since event studies of long-run returns focus on the common stock performance of corporations we delete the firm-month returns on securities identified by CRSP as other than ordinary common shares (CRSP share codes 10 and 11). Thus, for example, we exclude from our analysis returns on American Depository Receipts, closed-end funds, foreign-domiciled firms, Primes and Scores, and real estate investment trusts.

Fama and French (1992) document that common stock returns are related to firm size and book-to-market ratios. In developing a test to detect long-run abnormal stock returns, we anticipate that it will be important to control for firm size and book-to-market ratios. As in Fama and French (1992, 1993), we measure firm size in June of each year as the market value of common equity (shares outstanding multiplied by June closing price). Size rankings based on market 
value of equity in year $t$ are then used from July of year $t$ through June of year $t+1$. Thus, we further delete from our analysis firm-month returns from July of year $t$ through June of year $t+1$ without a size ranking in June of year $t$.

As in Fama and French (1992, 1993), we measure a firm's book-to-market ratio using the book value of common equity (Compustat data item 60) reported on the firm's balance sheet in year $t-1$ divided by the market value of common equity in December of year $t-1$. Rankings based on book-to-market ratios are then used from July of year $t$ through June of year $t+1$. The calculation of book-to-market ratios precedes their use for ranking purposes by a minimum of six months to allow for delays in the reporting of financial statements by corporations. Thus, we further delete from our analysis firm-month returns from July of year $t$ through June of year $t+1$ without a book-to-market ranking in year $t-1$. We also delete firms that report a book value of common equity that is less than or equal to zero, though this is relatively rare. Previous drafts of this paper excluded financial firms from the analysis, but the general tenor of the results was not affected.

Table 2 reconciles the firm-month returns reported on CRSP between July 1963 and December 1994 to our final population of over 1.1 million firm-month returns. The majority of the firm-month returns lost from our analysis are deleted as a result of requiring prior book-to-market data. We discuss the implication of this requirement at the close of this section. The 1.1 million firm-month returns correspond to the possible event months from which a researcher can draw a sample observation in a long-run event study.

In the remainder of this section, we consider three approaches for evaluating the returns of samples firms: a reference portfolio approach, a control firm

Table 2

Reconciliation of CRSP NYSE AMEX/NASDAQ firm-month returns to our final population of firmmonth returns on the ordinary common stock of firms with market value of equity in June of year $t$ and book-to-market ratio in year $t-1$ : July 1963 to December 1994

Description

Number of

firm-month returns

All valid firm-month returns

$1,798,509$

Less

Firm-month returns for other than ordinary common stock

136,849

Firm-month returns without a book-to-market ranking in year $t-1$

397.411

(but with a size ranking in year t)

Firm-month returns without a size ranking in year $t$ and without

85,574 a book-to-market ranking in year $t-1$ 
approach, and an application of the Fama-French three-factor model. Though financial economists have long recognized the importance of controlling for firm size in the calculation of long-run abnormal stock returns (see, for example, Dimson and Marsh, 1986), only recently have researchers controlled for both size and book-to-market patterns in studies that analyze long-run abnormal returns. While we develop and analyze reference portfolios and control firms based on size alone, we anticipate (and our results confirm) that in certain sampling situations it is critical to control for both size and book-to-market patterns in common stock returns.

In Table 3, we summarize many of the recent studies of long-run abnormal stock return performance following major corporate events and the benchmarks

Table 3

Summary of studies analyzing long-run abnormal stock returns following corporate events or decisions

\begin{tabular}{|c|c|c|}
\hline Author(s) & Corporate event studied & Return benchmark \\
\hline Bernard and Thomas (1989) & Earnings announcements & Market model ${ }^{\mathrm{a}}$ \\
\hline Ritter (1991) & Initial public offerings & $\begin{array}{l}\text { Market index } \\
\text { Size/industry control firm } \\
\text { Size portfolio }\end{array}$ \\
\hline $\begin{array}{l}\text { Agrawal, Jaffe. } \\
\text { and Mandelker (1992) }\end{array}$ & Acquisitions & Size portfolio \\
\hline Womack (1996) & Analyst recommendations & $\begin{array}{l}\text { Size portfolio } \\
\text { Three-factor model }\end{array}$ \\
\hline $\begin{array}{l}\text { lkenberry, Lakonishok, } \\
\text { and Vermaelen (1995) }\end{array}$ & Share repurchase & $\begin{array}{l}\text { Market index } \\
\text { Size portfolio } \\
\text { Size and book-to-market } \\
\text { portfolio }\end{array}$ \\
\hline Loughran and Ritter (1995) & $\begin{array}{l}\text { Initial public and } \\
\text { Seasoned equity offerings }\end{array}$ & $\begin{array}{l}\text { Market index } \\
\text { Size control firm } \\
\text { Three-factor model }{ }^{b}\end{array}$ \\
\hline $\begin{array}{l}\text { Spiess and Affleck- } \\
\text { Graves (1995) }\end{array}$ & Seasoned equity offerings & $\begin{array}{l}\text { Market index } \\
\text { Size portfolio } \\
\text { Size/industry control firm } \\
\text { Size/book-to-market } \\
\text { control firm }\end{array}$ \\
\hline $\begin{array}{l}\text { Michaely, Thaler. } \\
\text { and Womack (1995) }\end{array}$ & $\begin{array}{l}\text { Dividend initiation } \\
\text { and omission }\end{array}$ & $\begin{array}{l}\text { Market index } \\
\text { Size portfolio } \\
\text { Size/industry portfolio }\end{array}$ \\
\hline Desai and Jain (1996) & Stock splits and dividends & $\begin{array}{l}\text { Size portfolio } \\
\text { Book-to-market portfolio }\end{array}$ \\
\hline
\end{tabular}

a The authors apply a traditional market model and cumulate daily abnormal returns.

b The authors apply the three-factor model developed by Fama and French (1993). 
used in each of the studies. All of the studies summarized in Table 3 use some variation of the reference portfolio approach that we analyze. Recent studies use variations of the Fama-French three-factor model (e.g., Loughran and Ritter, 1995; Womack, 1996). Of the studies summarized in Table 3, only three use the control firm approach (Ritter, 1991; Loughran and Ritter, 1995; Spiess and Affleck-Graves, 1995). Of these three studies, only Loughran and Ritter (1995) report in a table the statistical significance of long-run abnormal returns using the control firm approach. ${ }^{2}$

\subsection{Reference portfolios}

Our first set of reference portfolios is ten size-based portfolios that are reconstituted in July of each year. In June of year $t$, we rank all NYSE firms in our population on the basis of market value of equity. Size deciles are then created based on these rankings for all NYSE firms. NASDAQ and AMEX firms are then placed in the appropriate NYSE size decile based on their June market value of equity. Since NASDAQ is populated predominantly with smaller firms, this ranking procedure leaves many more firms in the smallest decile of firm size than in the other nine deciles. Approximately $50 \%$ of all firms fall in the smallest size decile. Sorting on firm size without regard to exchange is problematic, since data on NASDAQ firms are only available beginning in 1972 .

We calculate the monthly return for each of the ten size reference portfolios by averaging the monthly returns across all securities in a particular size decile. Since we rank firms in June of each year, firms are allowed to change size deciles once each year. The calculation of the size-benchmark return is equivalent to a strategy of investing in an equally weighted size decile portfolio with monthly rebalancing.

Our second set of reference portfolios is ten book-to-market portfolios that are reconstituted in July of each year. In December of year $t-1$, we rank all NYSE firms in our population on the basis of book-to-market ratios. Book-tomarket deciles are then created based on these rankings for all NYSE firms. NASDAQ and AMEX firms are then placed in the appropriate book-to-market decile based on their book-to-market ratio in year $t-1$. The extreme deciles of book-to-market have slightly more firms than deciles two through nine: $17 \%$ of

\footnotetext{
${ }^{2}$ Additional research on long-run abnormal stock returns include studies of analyst recommendations (Desai and Jain, 1995), stock splits (Desai and Jain. 1996; lkenberry, Rakine, and Stice, 1996), initial public offerings (Field, 1996; Brav and Gompers, 1995: Michaely and Womack, 1996), seasoned equity offerings (Teoh, Welch, and Wong, 1995; Brav, Geczy, and Gompers, 1995: Lee, 1995), contrarian strategies (Loughran and Ritter, 1996), venture capital distributions (Gompers and Lemer, 1995), post-earnings-announcement drift (Brown and Pope, 1996), debt offerings (Spiess and AffleckGraves, 1996), pre-acquisition performance (Agrawal and Jaffe. 1996), post-acquisition performance (Rau and Vermaelen, 1996), short interest (Asquith and Muelbroek. 1996), and exchange listing (Dharan and Ikenberry, 1995).
} 
all firms are ranked in the lowest book-to-market decile and 14\% of all firms are ranked in the highest book-to-market decile. The returns on the ten book-tomarket reference portfolios are calculated in a fashion analogous to the ten size portfolios.

Our third set of reference portfolios is 50 size/book-to-market portfolios that are reconstituted in July of each year. These portfolios are formed in two steps. First, in June of year $t$, we rank all NYSE firms in our population on the basis of their market value of equity. Size deciles are then created based on these rankings for all NYSE firms. Second, within each size decile, firms are sorted into quintiles on the basis of their book-to-market ratios in year $t-1$. NASDAQ and AMEX firms are placed in the appropriate size/book-to-market portfolio based on their size in June of year $t$ and book-to-market ratio in year $t-1$. The returns on the 50 portfolios are calculated in a fashion analogous to the ten size portfolios and ten book-to-market portfolios.

Finally, in addition to the three sets of reference portfolios based on size and book-to-market ratios, we consider the use of the CRSP equally weighted NYSE/AMEX/NASDAQ market index. It may be informative from an investment perspective to compare the performance of sample firms to a value-weighted market index. However, such comparisons are inherently flawed when developing a test for detecting long-run abnormal returns because event studies by design give equal weight (rather than a value weight) to sample observations. In sum, we investigate the use of ten size portfolios, ten book-to-market portfolios, fifty size/book-to-market portfolios, and an equally weighted market index in tests for long-run abnormal stock returns.

\subsection{Control firms}

The use of reference portfolios to calculate cumulative abnormal returns is subject to the measurement, new listing, and skewness biases, while their use to calculate buy-and-hold abnormal returns is subject to the new listing, rebalancing, and skewness biases. As an alternative to the use of reference portfolios for the calculation of abnormal returns, we consider the use of control firms. In the control firm approach, sample firms are matched to a control firm on the basis of specified firm characteristics.

The control firm approach eliminates the new listing bias (since both the sample and control firm must be listed in the identified event month), the rebalancing bias (since both the sample and control firm returns are calculated without rebalancing), and the skewness problem (since the sample and control firms are equally likely to experience large positive returns). When cumulative abnormal returns are used to detect long-run abnormal stock returns, however, the measurement bias remains when the control firm approach is used. We evaluate the extent of this measurement bias at the close of Section 5. 
We evaluate three methods of identifying a control firm: (1) matching a sample firm to a control firm closest in size (as measured by market value of equity previously defined), (2) matching a sample firm to a control firm with most similar book-to-market ratio, and (3) matching a sample firm to a control firm of similar size and book-to-market ratio. When we match on both size and bookto-market, we first identify all firms with a market value of equity between $70 \%$ and $130 \%$ of the market value of equity of the sample firm; from this set of firms, we choose the firm with the book-to-market ratio closest to that of the sample firm. Variations on this matching scheme, such as filtering on book-tomarket and then matching on size, work well in most sampling situations, but we find that filtering on size and then matching on the book-to-market ratio yields test statistics that are well specified in virtually all sampling situations that we analyze.

\subsection{The Fama-French three-factor model}

Finally, we consider the use of the three-factor model developed by Fama and French (1993). The three-factor model is applied by regressing the post-event monthly excess returns for firm $i$ on a market factor, a size factor, and a bookto-market factor:

$$
R_{i t}-R_{i t}=\alpha_{i}+\beta_{i}\left(R_{m t}-R_{f t}\right)+s_{i} S M B_{t}+h_{i} H M L_{t}+\varepsilon_{i t},
$$

where $R_{i t}$ is the simple return on the common stock of firm $i, R_{f t}$ is the return on three-month Treasury bills, $R_{m t}$ is the return on a value-weighted market index, $S M B_{1}$ is the return on a value-weighted portfolio of small stocks less the return on a value-weighted portfolio of big stocks, and $H M L_{t}$ is the return on a value-weighted portfolio of high book-to-market stocks less the return on a value-weighted portfolio of low book-to-market stocks. ${ }^{3}$ The regression yields parameter estimates of $\alpha_{i}, \beta_{i}, s_{i}$, and $h_{i}$. The error term in the regression is denoted by $\varepsilon_{i t}$. The parameter of interest in this regression is the intercept, $\alpha_{i}$. A positive intercept indicates that after controlling for market, size, and book-tomarket factors in returns, a sample firm has performed better than expected.

The three-factor model offers the advantage that it does not require size or book-to-market data for sample firms. Removing this requirement has two implications. First, firms without available data on market value of equity or book-tomarket ratio can be included in the analysis. Second, some large firms or firms with low book-to-market ratios may in fact have common stock returns that more closely mimic those of small firms or firms with high book-to-market ratios. The three-factor model allows for this possibility since the pattern of returns, rather than the explicit measurement of size or book-to-market, determines whether the

\footnotetext{
${ }^{3}$ The construction of these factors are discussed in detail in Fama and French (1993). We thank Eugene Fama for providing us with these data.
} 
returns on a firm's common stock more closely mimic the returns of small firms and/or high book-to-market firms.

The three-factor model has two disadvantages. First, given four parameters in the regression, it requires at least five observations of monthly returns post-event. This creates a survivor bias among remaining sample firms. ${ }^{4}$ Second, when longhorizon returns (say five-year returns) are considered, the regression estimates are assumed stable over the estimation period. Thus, in contrast to the size/book-tomarket portfolios, in which a firm's portfolio assignment is allowed to change once per year, the regression approach assumes that a firm's market, size, and book-to-market characteristics are stable over time. ${ }^{5}$

\subsection{Survivor/selection biases in Compustat data}

Kothari, Shanken, and Sloan (1995) argue that survivor biases in Compustat data may partially explain the relation between book-to-market ratios and security returns. They argue that there are two sources of bias. First, prior to 1978, Compustat routinely included historical financial information of firms. Second, Compustat may back-fill the financial information of firms that delayed the reporting of their financial statements for reasons related to financial distress. The problem with this type of back-filling is that the firms that emerge from financial distress are more likely to be back-filled. However, the accumulating evidence suggests that there is a positive relation between book-to-market ratios and security returns (e.g., Davis, 1994; Chan, Jegadeesh, and Lakonishok, 1995; Barber and Lyon, 1996b). Furthermore, Chan, Jegadeesh, and Lakonishok (1995) argue that the survivor bias in Compustat data is small.

In this research, we are forced to either ignore the possible relation between book-to-market ratios and security returns or use data that we know are subject to some survivor bias (though the extent of the bias is contested). We choose to include book-to-market ratios in our analysis for four reasons. First, in event

\footnotetext{
4 It is not clear, ex ante, what effect this survivor bias has on tests for long-run abnormal returns. The direction of the bias depends on the returns of firms in the months immediately prior to delisting. In the case of a merger, acquisition, or going private transaction these returns are likely positive, while in the case of a bankruptcy or liquidation these returns are likely negative.

s An alternative application of the Fama-French three-factor model that we considered, which is analogous to a traditional market model approach, is to estimate three coefficients on the market risk premium, size factor, and book-to-market factor using a pre-event window. Expected returns can be calculated using the estimated coefficients. the risk-free rate, and the realized market, size, and book-to-market risk premiums. Post-event abnormal returns can be calculated using a sample firm's realized retum less an expected return. We abandoned this approach for two reasons. First, it requires pre-event return data - a requirement that is not necessary for the reference, control, or Fama-French methods that we consider. Second, the estimated coefficients on size and book-to-market are not stable over time, so that applying coefficient estimates from a pre-event estimation window introduces noise into an analysis of long-run abnormal stock returns.
} 
studies over long horizons, the survivor bias will lead to biases in results only if sample firms are more or less likely to have been back-filled by Compustat than the general population. A survivor bias in Compustat data is not sufficient to reject results that document significant long-horizon abnormal returns. Second, the bookto-market and size/book-to-market reference portfolio and control firm approaches should control well for the survivor biases in Compustat data. If book-to-market ratios are an instrument for survivor bias in Compustat data, we can control for the survivor bias inherent in Compustat data by matching sample firms to firms of similar book-to-market ratios. Third, we have reestimated all of our results in the 1979 through 1994 subperiod. Kothari, Shanken, and Sloan (1995) indicate that Compustat did not include historical financial information for firms in its database during this period, though the survivor bias from delayed financial reports persists. The general tenor of our results is similar during this subperiod. Fourth, we have reestimated our results by drawing samples from the population of firms described in Table 2, but without regard to the availability of book-to-market ratios. The results that employ size decile portfolios, size-matched control firms, the FamaFrench three-factor model, and the equally weighted market index are similar to those that we report later. Barber and Lyon (1996a) thoroughly discuss the impact of dropping the requirements for size and book-to-market data.

\section{Statistical tests for long-run abnormal stock returns}

We evaluate the empirical specification and power of test statistics based on both CARs (see Eq. (1)) and BHARs (see Eq. (2)) at one-, three-, and five-year horizons. We use the return on either a reference portfolio or a control firm as the expected return for each sample firm when calculating a CAR or BHAR.

It is common for some sample firms to delist their common stock post-event. For example, delisting can result from acquisition, bankruptcy, or going private. When a sample firm is missing return data post-event, we use the return on the corresponding reference portfolio as the realized return. In a random sample of 50,000 firms, we are forced to fill returns in at least one month out of 12 for 4,104 of these firms $(8.2 \%)$. Of these 4,104 firms, 1,138 are filled in just one month. Of the 600,000 firm-month returns $(50,000$ times 12 months $)$, we fill $20,889(3.5 \%)$ of the firm-month returns. When a control firm is missing return data post-event, we fill the control firm's return with the corresponding reference portfolio. For example, when sample firms are matched to control firms on size, we fill missing return data for control firms with the return on their corresponding size decile portfolio.

Our results are robust to truncating, rather than filling, the returns of sample firms. However, the sample mean long-run abnormal return calculated with truncation does not represent the average return an investor could earn from investing in an executable trading strategy, since the investor's use of the proceeds from 
an investment in a delisted firm is left unresolved. With filling, it is assumed that investors roll their investment from the delisted firm into a reference portfolio. For this reason, we choose to report results with filling rather than truncation.

We consider the use of four reference portfolios (size deciles, book-to-market deciles, 50 size/book-to-market portfolios, and an equally weighted NYSE/ASE/ NASDAQ market index) and three methods of identifying a control firm (sizematched, book-to-market matched, and size/book-to-market matched). When reference portolios are employed, if the portfolio assignment of a sample firm changes during the event year (say from size decile 10 to 9), the corresponding reference portfolio is also changed. When the control firm methods are used, the same control firm is used throughout the horizon of analysis.

\subsection{The statistical tests}

To test the null hypothesis that the mean cumulative or buy-and-hold abnormal returns are equal to zero for a sample of $n$ firms, we employ one of two parametric test statistics:

$$
t_{C A R}=\overline{C A R_{i \tau}} /\left(\sigma\left(C A R_{i \tau}\right) / \sqrt{n}\right)
$$

or

$$
t_{B H A R}=\overline{B H A R_{i \tau}} /\left(\sigma\left(B H A R_{i \tau}\right) / \sqrt{n}\right),
$$

where $\overline{C A R_{i \tau}}$ and $\overline{B H A R_{i \tau}}$ are the sample averages and $\sigma\left(C A R_{i \tau}\right)$ and $\sigma\left(B H A R_{i \tau}\right)$ are the cross-sectional sample standard deviations of abnormal returns for the sample of $n$ firms. If the sample is drawn randomly from a normal distribution, these test statistics follow a Student's $t$-distribution under the null hypothesis. While the CARs and BHARs are clearly nonnormal, the Central Limit Theorem guarantees that if the measures of abnormal returns in the cross-section of firms are independent and identically distributed drawings from finite variance distributions, the distribution of the mean abnormal return measure converges to normality as the number of firms in the sample increases.

We also consider, but abandon, the use of time-series standard deviations to calculate test statistics for CARs. We prefer the use of cross-sectional standard errors because requiring pre-event return data from which a time-series standard error can be estimated exacerbates the new listing bias. In addition, time-series standard deviations cannot be used to calculate a test statistic for BHARs. This issue is discussed in detail by Barber and Lyon (1996a).

\subsection{The Fama-French three-factor model}

Finally, we consider the application of the Fama-French three-factor model. For a sample of $n$ firms, we estimate $n$ regressions (one for each sample firm). 
The intercept terms from these regressions (xs) are then averaged across the $n$ sample firms. A parametric $t$-statistic is calculated by dividing the mean intercept term by the cross-sectional sample standard deviation of the intercept terms and mulitplying by the square root of $n$. The mean intercept term is used to test the null hypothesis that the mean monthly abnormal return of sample firms is equal to zero. Thus, this application of the Fama-French three-factor model is conceptually equivalent to the tests based on cumulative abnormal returns.

\subsection{Simulation method}

To test the specification of the test statistics based on each of the four reference portfolios, the three control firm methods, and the three-factor model, 1,000 random samples of $n$ event months are drawn without replacement. (Our results are robust to sampling with replacement.) Since our unit of observation is an event month, we are more likely to sample firms with a longer history of return data. We believe that this is sensible, since most event studies analyze events that are proportional to the history of a firm. For example, firms with longer histories will have more equity or debt issues. For each of the 1,000 random samples, the test statistics are computed as described above and compared to the critical value of the test statistic associated with the two-tailed $\alpha$ significance level. Sampling first by firm and then by event month, which is how Kothari and Warner (1996) conduct their simulations, exacerbates the negative bias of test statistics documented in Section 5; the details of this analysis are discussed in Barber and Lyon (1996a).

If a test is well specified, $1,000 x$ tests will reject the null hypothesis of zero mean abnormal returns. A test is conservative if fewer than $1,000 x$ null hypotheses are rejected, while a test is anticonservative if more than $1,000 x$ null hypotheses are rejected. Based on this procedure, we test the specification of each test statistic at the $1 \%, 5 \%$, and $10 \%$ theoretical levels of significance. A wellspecified two-tailed test of the null hypothesis of zero mean abnormal returns will reject the null at the theoretical rejection level in favor of the alternative hypothesis of negative (positive) abnormal returns in $1,000 \alpha / 2$ samples. Thus, we separately document rejections of the null hypothesis in favor of the alternative hypothesis that long-run abnormal returns are positive or negative. For example, at the $1 \%$ theoretical significance level, we document the percentage of calculated $t$-statistics that are less than the theoretical cumulative density function of the $t$-statistic at $0.5 \%$ and greater than the theoretical cumulative density function at $99.5 \%$. Finally, to evaluate the impact of the new listing, rebalancing, and skewness biases, we also compute the mean and skewness for abnormal returns across all 1,000 samples times $n$ observations for each simulation.

In sum, we calculate the empirical specification of test statistics based on (1) 15 methods of calculating abnormal returns (CARs using the four reference 
Table 4

Summary of methods for calculating abnormal returns and methods for developing a return benchmark

$R_{i t}$ is the monthly return of a sample firm and $\mathrm{E}\left(R_{i t}\right)$ is the expected return. The expected return is the return on one of four reference portfolios (size, book-to-market, size/book-to-market, or market index) or the return on a control firm (size-matched, book-to-market matched, or size/book-to-market matched). Abnormal returns over $\tau$ periods are calculated by either summing monthly abnormal returns for each sample firm, which we refer to as cumulative abnormal returns (CARs), or by subtracting the $\tau$ period buy-and-hold return of the benchmark from the $\tau$ period buy-and-hold return of the sample firm, which we refer to as buy-and-hold abnormal returns (BHARs). For early delisting, a reference portfolio is spliced in for BHAR calculations.

Methods of calculating abnormal returns

\begin{tabular}{|c|c|c|}
\hline Benchmark method & $\sum_{i=1}^{\mathrm{CARs}}\left[R_{i t}-\mathrm{E}\left(R_{i t}\right)\right]$ & $\prod_{t=1}^{\mathrm{BHARs}}\left[1+R_{i t}\right]-\prod_{t=1}^{\tau}\left[1+\mathrm{E}\left(R_{i t}\right)\right]$ \\
\hline Reference portfolios & $\begin{array}{l}\text { Size decile portfolios } \\
\text { Book-to-market decile portfolios } \\
\text { Fifty size/book-to-market } \\
\text { portfolios } \\
\text { Equally weighted market index }\end{array}$ & $\begin{array}{l}\text { Size decile portfolios } \\
\text { Book-to-market decile portfolios } \\
\text { Fifty size/book-to-market } \\
\text { portfolios } \\
\text { Equally weighted market index }\end{array}$ \\
\hline Control firm & $\begin{array}{l}\text { Size-matched } \\
\text { Book-to-market matched } \\
\text { Size/book-to-market matched }\end{array}$ & $\begin{array}{l}\text { Size-matched } \\
\text { Book-to-market matched } \\
\text { Size/book-to-market matched }\end{array}$ \\
\hline $\begin{array}{l}\text { Fama-French } \\
\text { three-factor model }\end{array}$ & Regression intercept $(x)$ & Not applicable \\
\hline
\end{tabular}

a The CRSP equally weighted NYSE/AMEX/NASDAQ market index is used.

${ }^{b}$ Post-event monthly excess returns of each sample firm are regressed on a market, size, and bookto-market risk premium. The mean intercept term across all sample firms is used to test the null hypothesis that the mean post-event monthly abnormal return is zero. This is functionally equivalent to a test of the null hypothesis that the mean summed monthly abnormal returns, which we refer to as cumulative abnormal returns, are equal to zero. Thus, we categorize this application of the Fama-French three-factor model under the heading cumulative abnormal returns.

portfolios, three control firm methods, and the Fama-French three-factor model; BHARs using the four reference portfolios and the three control firm methods), (2) a $t$-statistic, (3) one-, three-, and five-year returns, and (4) the $1 \%, 5 \%$, and $10 \%$ theoretical significance levels. This yields 135 permutations of our analysis of the specification of test statistics for long-run abnormal returns in random samples. In Table 4, we summarize the different methods for calculating long-run abnormal returns (CARs vs. BHARs) and the different approaches to constructing a benchmark (reference portfolios, control firms, and the Fama-French threefactor model). 


\section{Results}

In this section, we document the specification and power of $t$-statistics using long-run CARs and BHARs. We begin with a discussion of the results in random samples, followed by a discussion of results in samples with size-based and book-to-market based sampling biases. We close this section with a discussion of measurement bias associated with the use of CARs. In discussing our results, we liberally refer to the new listing, skewness, and rebalancing biases outlined in detail in Section 2.

\subsection{Random samples}

\subsubsection{Cumulative abnormal returns}

The first set of results is based on 1,000 random samples of 200 event months drawn from our population of over 1.1 million possible event months. The specification of $t$-statistics using 12-month, 36-month, and 60-month CARs and the Fama-French three-factor model is presented in Table 5. Recall that these $t$-statistics test the null hypothesis that the mean monthly abnormal return during the event period is zero.

Three results are noteworthy. First, cumulative abnormal returns calculated using reference portfolios yield test statistics that are positively biased. The magnitude of the bias increases with the horizon of cumulation. This positive bias can be attributed to the positive mean abnormal return, which results from the new listing bias. Note that this positive bias is most pronounced when an equally weighted market index is used to calculate the CARs. This result can be traced to the fact that firms included in the size, book-to-market, and size/book-to-market reference portfolios must have prior period data on size and book-to-market ratios. This requirement for prior-period data for firms constituting the index mitigates (but does not eliminate) the new listing bias.

Second, all of the control firm approaches yield well-specified test statistics. (The one exception is the size-matched control firm approach at the $5 \%$ significance level and 36 months. We suspect random sampling variation accounts for this result.) Note that when the control firm approaches are employed at 36- and 60 -month horizons, the resulting mean CAR is more closely centered on zero than is the mean CAR calculated using reference portfolios. The control firm approach effectively eliminates the new listing bias.

Third, the Fama-French three-factor model yields negatively biased test statistics at 12- and 36-month horizons. Fama and French (1993, Table 9a) document that portfolios of small firms yield negative intercepts when regressed on their three factors. Similarly, when we regress the monthly return on the CRSP equally weighted market index less the return on Treasury bills on the FamaFrench factors from July 1963 to December 1994 the resulting intercept term is $-0.08 \%$. Recall that event studies give equal weight to sample observations, 
so this experiment provides us with a rough estimate of the magnitude of the negative bias in long-run event studies. At longer horizons, the negative bias in the Fama-French three-factor model is moderated by the new listing bias. The result is a reduced negative bias in test statistics at 36 months and well-specified test statistics at 60 months. The extreme skewness measures for $\alpha$ 's at 12 and 36 months are misleading and the result of fewer than ten extreme observations. When the five most positive and five most negative $x$ 's are deleted from the

Table 5

Specification (size) of $t$-statistics using CARs in random samples

Percentage of $t$-statistics in 1,000 random samples of 200 firms (1963-1994) rejecting the null of zero 12-month, 36-month, or 60-month cumulative abnormal returns (CAR) at the 1\%, 5\%, and 10\% theoretical significance level

The numbers presented in the body of this table represent the percentage of 1,000 random samples of 200 firms that reject the null hypothesis of no 12-month (panel A), 36-month (panel B), or 60-month (panel $\mathrm{C}$ ) cumulative abnormal returns at the theoretical significance level of $1 \%, 5 \%$, and $10 \%$ in favor of the alternative hypothesis of a significantly negative CAR. (i.e., calculated $p$-value is less than $0.5 \%$ at the $1 \%$ significance level) or a significantly positive CAR (calculated $p$-value is greater than $99.5 \%$ at the $1 \%$ significance level)

Two-tailed theoretical significance level (\%):

Theoretical cumulative density function $(\%)$ : Description of return benchmark

$\begin{array}{ccccc}\frac{1}{0.5 \quad 99.5} & \frac{5}{2.5} \quad 97.5 & \frac{10}{5.0} \quad 95.0\end{array}$

Panel A: 12-month CARs

Size deciles

Book-to-market deciles

Fifty size/book-to-market portfolios

Equally weighted market index ${ }^{\mathrm{a}}$

Size-matched control firm

Book-to-market matched control firm

Sizc book-to-market matched control firm 0

Fama-French three-factor model $x^{\mathrm{s}} \mathrm{s}^{\mathrm{b}}$

\begin{tabular}{llllllrr}
0.6 & 0.2 & 2.9 & 2.0 & 5.0 & 5.2 & 0.10 & 2.04 \\
0.6 & 0.1 & 3.1 & 1.1 & 5.3 & 4.5 & -0.05 & 2.15 \\
$1.1^{*}$ & 0.1 & 3.2 & 1.4 & 5.1 & 4.6 & -0.02 & 2.13 \\
0.1 & 0.4 & 1.5 & $3.7^{*}$ & 3.1 & $7.7^{*}$ & 0.82 & 2.05 \\
0.6 & 0.6 & 3.0 & 2.2 & 5.3 & 3.9 & -0.23 & -0.03 \\
0.7 & 0.8 & 2.9 & 2.6 & 5.3 & 4.9 & -0.31 & -0.36 \\
0.4 & 0.3 & 2.3 & 1.6 & 4.7 & 3.2 & -0.28 & -0.04 \\
$1.6^{*}$ & 0.0 & $6.1^{*}$ & 1.0 & $11.6^{*}$ & 2.2 & -1.51 & 17.72 \\
\hline
\end{tabular}

Panel B: 36-month CARs

\begin{tabular}{lllllllll} 
Size deciles & 0.2 & $1.2^{*}$ & 1.1 & $5.3^{*}$ & 3.1 & $9.3^{*}$ & 1.52 & 1.15 \\
Book-to-market deciles & 0.3 & 0.5 & 2.6 & 3.1 & 4.8 & 5.8 & 0.32 & 1.23 \\
Fifty size/book-to-market portfolios & 0.2 & 0.6 & 2.2 & $3.5^{*}$ & 4.6 & $6.9^{*}$ & 0.69 & 1.20 \\
Equally weighted market index & 0.1 & $2.9^{*}$ & 0.5 & $9.7^{*}$ & 1.4 & $15.8^{*}$ & 3.46 & 1.18 \\
Size-matched control firm & 0.2 & 0.6 & 3.0 & $3.6^{*}$ & 6.0 & 6.1 & -0.60 & -0.46 \\
Book-to-market matched control firm & 0.8 & 0.8 & 2.3 & 2.7 & 5.6 & 5.4 & -0.28 & -0.18 \\
Size book-to-market matched control firm & 0.3 & 0.4 & 2.8 & 2.2 & 6.0 & 4.4 & -0.56 & -0.11 \\
Fama-French three-factor model $x^{\prime} s^{b}$ & 0.2 & 0.2 & 2.3 & 2.4 & $6.9^{*}$ & 4.1 & -0.86 & 35.93 \\
\hline
\end{tabular}


Table 5 (continued)

Two-tailed theoretical significance level $(\%)$ : Theoretical cumulative density function $(\%)$ : Description of return benchmark

$\frac{1}{0.5 \quad 99.5} \frac{5}{2.5 \quad 97.5} \frac{10}{5.0 \quad 95.0}$

Panel C: 60-month CARs

$\begin{array}{llllllrrr}\text { Size deciles } & 0.0 & 2.4^{*} & 0.6 & 8.0^{*} & 1.2 & 14.7^{*} & 3.45 & 1.11 \\ \text { Book-to-market deciles } & 0.1 & 0.7 & 1.9 & 4.4^{*} & 2.6 & 7.6^{*} & 1.47 & 1.24 \\ \text { Fifty size/book-to-market portfolios } & 0.2 & 1.3^{*} & 0.9 & 5.5^{*} & 2.2 & 10.0^{*} & 2.10 & 1.21 \\ \text { Equally weighted market index } & 0.0 & 5.5^{*} & 0.2 & 17.3^{*} & 0.5 & 25.1^{*} & 6.27 & 1.11 \\ \text { Size-matched control firm } & 0.6 & 0.3 & 2.1 & 2.2 & 5.2 & 4.3 & -0.59 & -0.14 \\ \text { Book-to-market matched control firm } & 0.4 & 0.8 & 2.9 & 3.1 & 5.2 & 5.4 & 0.00 & -0.01 \\ \text { Size/book-to-market matched control firm } & 0.2 & 0.4 & 2.4 & 2.3 & 4.3 & 4.3 & -0.63 & 0.07 \\ \text { Fama-French three-factor model } x^{\prime} \mathrm{s}^{\mathrm{b}} & 0.5 & 0.3 & 2.1 & 2.3 & 4.9 & 5.1 & -0.94 & -1.76\end{array}$

* Significantly different from the theoretical significance level at the $5 \%$ level, one-sided binomial test-statistic.

a The market index is the CRSP equally weighted NYSE/AMEX/NASDAQ portfolio.

${ }^{b}$ The mean $x$ from the 200,000 time-series regressions is converted to a 12-, 36-, or 60-month CAR by multiplying by 12,36 , or 60 .

200,000 random observations, the skewness measures at 12 and 36 months are both slightly greater than three.

We are also interested in the power of $t$-statistics using CARs. We document the power of $t$-statistics based on the eight methods of calculating abnormal returns by adding a constant level of abnormal return to the calculated cumulative abnormal return of each sample firm. For example, adding 5\% to the calculated CAR for a particular sample firm is equivalent to adding $0.42 \%$ ( $5 \% / 12$ months) to each of the 12 monthly returns of the sample firm. When the three-factor model is applied, we add the equivalent monthly abnormal return to the observed monthly return of each sample firm. We document the empirical rejection rates at the $5 \%$ theoretical significance level of the null hypothesis that the mean sample CAR is zero across 1,000 simulations at induced levels of abnormal returns ranging from $-20 \%$ to $+20 \%$ in increments of $5 \%$. Table 6 documents the empirical rejection rates in random samples at the various levels of induced abnormal returns for the eight methods. The reference portfolio methods are generally more powerful than the control firm methods, regardless of the reference portfolio or control firm method employed. However, the power of the reference portfolio approaches is meaningless, since they yield test statistics that are misspecified at long horizons. The power function of the three-factor model, which also yields misspecified test statistics, is clearly asymmetric. 
Table 6

Power of $t$-statistics using 12-month CARs in random samples

Percentage of 1.000 random samples of 200 firms (1963 1994) with induced abnormal returns ranging from $-20 \%$ to $+20 \%$ rejecting the null hypothesis of zero 12 -month cumulative abnormal return (CAR) at $5 \%$ theoretical significance level

The numbers presented in the body of this table represent the percentage of 1,000 random samples that reject the null hypothesis of no abnormal returns at the theoretical significance level of $5 \%$ and various levels of induced abnormal returns. Abnormal returns are induced by adding a constant to the observed cumulative abnormal return for each of the 200 randomly selected firms in all 1,000 random samples. Thus, for example, adding $5 \%$ to the 12 -month CAR is equivalent to a $0.42 \%$ monthly abnormal return.

\begin{tabular}{lrrrrrrrrr} 
Induced level of abnormal return (\%): & -20 & -15 & -10 & -5 & 0 & 5 & 10 & 15 & 20 \\
Description of return benchmark & & & & & & & & & \\
\hline Size deciles & 99 & 98 & 82 & 35 & 5 & 32 & 87 & 100 & 100 \\
Book-to-market deciles & 99 & 98 & 84 & 36 & 4 & 30 & 86 & 100 & 100 \\
Fifty size/book-to-market portfolios & 99 & 98 & 84 & 36 & 5 & 32 & 87 & 100 & $100^{\dagger}$ \\
Equally weighted NYSE/AMEX & & & & & & & & & \\
NASDAQ index & 99 & 97 & 76 & 25 & 5 & 39 & 91 & 100 & $100^{\dagger}$ \\
Size-matched control firm & 98 & 89 & 59 & 19 & 5 & 17 & 56 & 86 & 98 \\
Book-to-market matched control firm & 98 & 88 & 58 & 21 & 6 & 17 & 54 & 86 & 97 \\
Size book-to-market matched control firm & 98 & 89 & 60 & 20 & 4 & 15 & 56 & 87 & 98 \\
Fama-French three-factor model $x ' s$ & 96 & 88 & 66 & 28 & 7 & 9 & 32 & 66 & $87^{\dagger}$
\end{tabular}

${ }^{\dagger}$ Empirical tests based on this statistic are anticonservative at the $1 \%, 5 \%$. and or $10 \%$ theoretical significance level (see Table 5).

\subsubsection{Buy-and-hold abnormal returns}

The specification of $t$-statistics using long-run buy-and-hold returns is presented in Table 7. Recall that these test statistics test the null hypothesis that the annual abnormal return is zero. We highlight two results of this analysis. First, there is a significant negative bias in $t$-statistics based on abnormal returns calculated using the four reference portfolios. The negative bias can ultimately be traced to the rebalancing and skewness biases. Though the new listing bias generally leads to positive mean CARs (particularly at long horizons), the rebalancing bias more than offsets the new listing bias when BHARs are calculated using a reference portfolio. The result is a negative mean BHAR. The one exception to this result is at five years when the equally weighted index is used. (Recall that the use of size, book-to-market, and size/book-to-market reference portfolios mitigates the new listing bias due to the requirement that firms included in a reference portfolio have prior-period data.)

The skewness bias also exacerbates the negative bias in test statistics. Note that the skewness of BHARs is much more pronounced than that of CARs. The effect of skewness on test statistics is best revealed on close inspection of five-year 
results when an equally weighted index is used (panel $\mathrm{C}$, Table 7). As previously noted, this is one case in which the new listing bias dominates the rebalancing bias, leading to a positive mean five-year BHAR. However, despite the positive mean five-year BHAR, test statistics remain negatively biased because of the severe skewness of BHARs calculated using reference portfolios. A revised test statistic proposed by Hall (1992, p. 222) that adjusts the calculated test statistic based on the observed sample skewness (third sample moment) marginally improves the specification of the test statistics, but the negative bias remains.

Table 7

Specification (size) of $t$-statisties using BHAR in random samples

Percentage of $t$-statistics in 1.000 random samples of 200 firms (1963-1994) rejecting the null of zero annual. three-year. or five-year buy-and-hold abnormal returns (BHAR) at the 1\%, 5\%, and 10\% theoretical significance level

The numbers presented in the body of this table represent the percentage of 1.000 random samples of 200 firms that reject the null hypothesis of no annual (panel A). three-year (panel B). or five-year (panel $\mathrm{C}$ ) buy-and-hold abnormal return at the theoretical significance level of $1 \%, 5 \%$, and $10 \%$ in favor of the alternative hypothesis of a significantly negative BHAR (i.e.. calculated $p$-value is less than $0.5 \%$ at the $1 \%$ significance level) or a significantly positive BHAR (calculated $p$-value is greater than $99.5 \%$ at the $1 \%$ significance level).

Two-tailed theoretical significance level $(\%)$ : Theoretical cumulative density function $(\%)$ :

Description of return benchmark

Mean Skew

Panel A: Annual BHAR

Size deciles

Book-to-market deciles

Fifty size: book-to-market portfolios

Equally weighted market inde $x^{a}$

Size-matched control firm

Book-to-market matched control firm

Size book-to-market matched control firm

$\begin{array}{lrrrrrrr}3.8^{*} & 0.0 & 9.1^{*} & 0.0 & 14.4^{*} & 1.1 & -1.20 & 7.96 \\ 4.7^{*} & 0.0 & 10.0^{*} & 0.1 & 15.6^{*} & 0.7 & -1.46 & 8.12 \\ 4.3^{*} & 0.0 & 10.0^{*} & 0.1 & 15.8^{*} & 0.9 & -1.43 & 8.10 \\ 2.1^{*} & 0.0 & 7.3^{*} & 0.4 & 10.5^{*} & 1.9 & -0.48 & 7.99 \\ 0.1 & 0.3 & 2.8 & 2.5 & 5.6 & 4.7 & -0.08 & 0.38 \\ 0.9^{*} & 0.3 & 2.6 & 1.8 & 5.3 & 4.0 & -0.32 & 0.98 \\ 0.3 & 0.3 & 1.9 & 1.3 & 5.2 & 3.5 & -0.21 & -0.54\end{array}$

Panel B: Three-year BHAR

Size decilcs

$\begin{array}{lll}5.2^{*} & 0.0 & 10.4^{*} \\ 6.8^{*} & 0.0 & 14.5^{*} \\ 7.1^{*} & 0.0 & 14.5^{*} \\ 2.2^{*} & 0.0 & 6.5^{*} \\ 0.8 & 0.6 & 3.2 \\ 0.6 & 0.7 & 2.4 \\ 0.4 & 0.3 & 2.3\end{array}$

$0.115 .2^{*}$

$1.3-3.14$

6.97

Book-to-market deciles

0.1 $21.9^{*}$

$0.7-5.43$

7.00

Fifty size book-to-market portfolios

$0.020 .1^{*}$

$0.5-5.24$

6.89

Equally weighted market index

$1.010 .0^{\infty}$

$2.4-0.10$

7.16

Size-matched control firm

$2.8 \quad 5.4$

$5.7-0.20$

0.33

Book-to-market matched control firm

$2.1 \quad 5.5$

$4.4 \quad 0.00 \quad-0.36$

Size book-to-market matched control firm

$\begin{array}{llll}0.3 & 2.3 & 2.4 & 5.0\end{array}$

$\begin{array}{lll}5.1 & -0.85 & -0.27\end{array}$ 
Table 7 (continued)

Two-tailed theoretical significance level $(\%)$ : Theoretical cumulative density function $(\%)$ : Description of return benchmark

Mean Skew

Panel C: Five-year BHAR

Size deciles

Book-to-market deciles

Fifty size/book-to-market portfolios

Equally weighted market index ${ }^{\text {a }}$

$\frac{1}{0.5 \quad 99.5}-\frac{2}{2.5 \quad 97.5}-\frac{10}{5.0 \quad 95.0}$

Size-matched control firm

Book-to-market matched control firm

Size book-to-market matched control firm

$\begin{array}{rrrrrrrr}4.2^{*} & 0.0 & 9.8^{*} & 0.6 & 15.7^{*} & 1.0 & -4.86 & 12.48 \\ 7.8^{*} & 0.0 & 15.8^{*} & 0.1 & 23.1^{*} & 0.3 & -9.62 & 12.35 \\ 7.2^{*} & 0.0 & 16.3^{*} & 0.2 & 23.1^{*} & 0.7 & -9.67 & 12.19 \\ 1.6^{*} & 0.1 & 4.4^{*} & 0.7 & 7.7^{*} & 2.5 & 2.00 & 12.66 \\ 0.6 & 0.4 & 3.1 & 2.6 & 5.3 & 5.1 & 0.08 & 1.51 \\ 0.3 & 0.4 & 2.0 & 2.2 & 4.0 & 4.8 & 1.46 & 2.55 \\ 0.3 & 0.1 & 2.5 & 2.4 & 5.0 & 3.9 & -1.12 & 1.61\end{array}$

* Significantly different from the theoretical significance level at the $5 \%$ level, one-sided binomial test-statistic.

'The market index is the CRSP equally weighted NYSE/AMEX/NASDAQ portfolio.

The second noteworthy result is the efficacy of the control firm approach. When the control firm approaches are employed, the mean BHAR and skewness are generally both much closer to zero than when the reference portfolio approach is used. As argued previously, the control firm approach alleviates the new listing, rebalancing, and skewness biases that plague BHARs calculated using reference portfolios. Thus, test statistics based on the control firm approach are well specified. (The one exception is the book-to-market matched control firm approach at the $1 \%$ significance level and an annual horizon. We suspect random sampling variation accounts for this result.)

As was done for CARs, we analyze the empirical power of the various test statistics by adding a constant level of abnormal return to the calculated annual BHAR of each sample firm. However, with buy-and-hold abnormal returns, adding $5 \%$ to the annual BHAR does not correspond to a particular pattern of monthly abnormal returns. Thus, direct comparisons of the power of $t$-statistics using CARs (presented in Table 6) and BHARs (presented in Table 8) are not meaningful. Table 8 documents the empirical rejection rates in random samples at the various levels of induced abnormal returns for the seven methods. Two observations emerge from this analysis. First, the reference portfolio methods of calculating annual buy-and-hold abnormal returns yield asymmetric power functions. Second, though symmetric, the control firm methods are less powerful than the reference portfolio methods. Nonetheless, we cannot recommend the use of the reference portfolio methods because they yield severely misspecified test statistics. 
Table 8

Power of $t$-statistics using annual BHAR in random samples

Percentage of 1,000 random samples of 200 firms (1963-1994) with induced abnormal returns ranging from $-20 \%$ to $+20 \%$ rejecting null hypothesis of zero annual buy-and-hold abnormal return (BHAR) at $5 \%$ theoretical significance level

The numbers presented in the body of this table represent the percentage of 1,000 random samples that reject the null hypothesis of no annual buy-and-hold abnormal returns at the theoretical significance level of $5 \%$ and various levels of induced abnormal returns. Abnormal returns are induced by adding a constant to the observed buy-and-hold abnormal return for each of the 200 randomly selected firms in all 1,000 random samples.

\begin{tabular}{lrrrrrrrrr}
\hline $\begin{array}{l}\text { Induced level of abnormal return (\%): } \\
\text { Description of return benchmark }\end{array}$ & -20 & -15 & -10 & -5 & 0 & 5 & 10 & 15 & 20 \\
\hline Size deciles & & & & & & & & & \\
Book-to-market deciles & 97 & 91 & 77 & 42 & 9 & 11 & 57 & 96 & $100^{\dagger}$ \\
Fifty size/book-to-market portfolios & 97 & 92 & 79 & 44 & 10 & 9 & 55 & 95 & $100^{\dagger}$ \\
Equally weighted NYSE/AMEX/NASDAQ index & 97 & 92 & 78 & 44 & 10 & 10 & 56 & 96 & $100^{\dagger}$ \\
Size-matched control firm & 91 & 90 & 72 & 35 & 8 & 14 & 66 & 97 & $100^{\dagger}$ \\
Book-to-market matched control firm & 91 & 75 & 46 & 17 & 4 & 13 & 42 & 72 & $90^{\dagger}$ \\
Size/book-to-market matched control firm & 92 & 76 & 47 & 15 & 3 & 13 & 43 & 74 & 91
\end{tabular}

${ }^{\dagger}$ Empirical tests based on this statistic are anticonservative at the $1 \%, 5 \%$, and $/$ or $10 \%$ theoretical significance level (see Table 7).

\subsection{Sampling biases}

We also analyze the empirical power and specification of test statistics in samples of firms from the smallest size decile, the largest size decile, the lowest book-to-market decile, and the highest book-to-market decile. We highlight two results of this analysis, the full details of which are available on request. First, the reference portfolios and the three-factor model yield misspecified test statistics in all of these sampling situations. Second, the size/book-to-market control firm approach yields well-specified test statistics in all of these sampling situations, with the exception of samples of large firms. At the $5 \%$ theoretical significance level, the size/book-to-market matched control firm approach rejects the null hypothesis of no annual BHAR in favor of the alternative of negative (positive) annual BHAR in $3.5 \%(1.2 \%)$ of all samples. We suspect the small negative bias, which is also evident at the three- and five-year horizons, is a result of the algorithm that we use to filter on firm size. Among large firms, applying a symmetric filter of $70-130 \%$ to identify a potential set of control firms likely results in more firms that are smaller than the sampled firm. This systematic bias toward smaller control firms renders the abnormal returns slightly negatively biased. 


\subsection{Measurement bias}

Recall that conceptually we favor the use of buy-and-hold abnormal returns for two reasons. First, they measure the underlying parameter of interest, which is the long-run performance of the common stock of sample firms relative to an appropriate comparison group. For example, a mean annual BHAR of $5 \%$ can be interpreted as the additional return earned from investing in a sample firm relative to a control firm over the year. In contrast, a 12-month CAR of 5\% does not readily translate into a measure of annual performance. The second reason that we favor the use of BHARs is that CARs are a biased predictor of BHARs (see Section 2).

To assess the extent of the measurement bias, we conduct the following experiment. In each of our simulations, we analyze the CARs and BHARs for the same sets of 1,000 samples. In each of the 1,000 samples at the 5\% theoretical significance level, we determine in what proportion of these samples a researcher would draw different inferences based on BHARs and CARs. For example, if at the $5 \%$ theoretical significance level a researcher would reject the null hypothesis of no abnormal returns when BHARs are employed, but fails to reject when CARs are employed, we would characterize this as a different inference based on BHARs and CARs. In this experiment, we use the size/book-to-market control firm approach, since this method yields well-specified test statistics for both CARs and BHARs in most sampling situations. (It is not useful to compare the inferences drawn from CARs and BHARs calculated using reference portfolios, since CARs and BHARs are differentially affected by the new listing, rebalancing, and skewness biases.)

Based on this analysis, we find that a researcher would obtain different inferences in $3.7 \%$ of 1,000 randomly selected samples of 200 observations. Among samples of small firms, this figure increases to $4.7 \%$.

\section{Tests of median return performance}

We also consider a nonparametric Wilcoxon signed-rank test statistic. We use the large-sample approximation for the Wilcoxon signed-rank test statistic described by Hollander and Wolfe (1973). If rankings are tied, the average ranks are used. The Wilcoxon signed-rank test statistic tests the null hypothesis that the median abnormal return is equal to zero. This may be a particularly useful hypothesis to test when a researcher is concerned with making inferences about the median firm in a particular sample. For example, Ritter (1991) argues that firms that go public do so partially to take advantage of a window of opportunity in which their stock is overvalued. Tests of the null hypothesis that the mean annual BHAR is zero do not allow us to conclude that the median firm is able to take advantage of a window of opportunity, since a negative mean BHAR 
can be driven by unusually large negative abnormal returns for a few sample firms.

The positive skewness in annual BHARs calculated using reference portfolios renders Wilcoxon signed-rank test statistics hopelessly misspecified (recall that the median BHAR calculated using a market index is $-7 \%$ ). For example, when a reference portfolio is used to calculate abnormal returns, the null hypothesis of a zero median annual BHAR is rejected in favor of the alternative hypothesis of a negative median annual BHAR in from $52 \%$ to $65 \%$ of random samples of size 200 at the $5 \%$ theoretical significance level. The positive skewness in 12-month CARs calculated using reference portfolios, though less severe, still yields negatively biased test statistics. At the 5\% two-tailed theoretical significance level, the rejections of the null hypothesis in favor of the alternative hypothesis of a negative median annual BHAR range from $3.6 \%$ to $7.3 \%$.

In order to obtain a well-specified test of the null hypothesis that the median annual BHAR is zero, a researcher must match sample firms to an appropriate control firm. We find that the size/book-to-market control firm method yields well-specified Wilcoxon test statistics in all sampling situations that we analyze. The results for tests on the median 12-month CAR are similar. As for $t$-statistics, there is a slight negative bias in the Wilcoxon test statistic among samples of large firms, which we suspect can be traced to our algorithm for matching on firm size.

We also analyze the power of the Wilcoxon test statistic using the same procedure previously described. These results (not reported in a table) indicate that it is somewhat easier to detect nonzero median abnormal returns than nonzero mean abnormal returns. With the size/book-to-market matched control firm method, a $10 \%(-10 \%)$ abnormal return added to each of our sampled firms enables us to reject the null hypothesis of a zero median BHAR in $70 \%(73 \%)$ of our 1,000 random samples of 200 firms. The corresponding rejection rates for testing the null hypothesis of a zero mean annual BHAR are $47 \%$ and $43 \%$ (see Table 8 ). The results are similar for 12-month CARs.

\section{Conclusion}

We document the empirical power and specification of test statistics used in event studies designed to detect long-run (one- to five-year) abnormal stock returns. We analyze two main issues in this research. First, we consider the calculation of abnormal returns. Second, we evaluate three general approaches for developing a benchmark for the calculation of long-run abnormal returns, including: (1) a reference portfolio, (2) an appropriately matched control firm, and (3) an application of the Fama-French three-factor model.

We argue that long-run abnormal returns should be calculated as the long-run buy-and-hold return of a sample firm less the long-run return of an appropriate benchmark, to which we refer as a buy-and-hold abnormal return. We advocate 
the use of buy-and-hold abnormal returns over cumulative abnormal returns for two reasons. First, we document that CARs are biased predictors of BHARs. This problem at its worst can lead to incorrect inferences. For example, we document that a sample of firms that all have zero annual buy-and-hold abnormal returns calculated relative to a market benchmark has a corresponding 12-month mean cumulative abnormal return of $+5 \%$, on average. In this sampling situation, researchers who restrict their analysis to cumulative abnormal returns and ignore the analysis of buy-and-hold abnormal returns could conceivably conclude that the sample in question earned long-run abnormal returns when in fact it did not. In random samples, we document that researchers would draw different inferences using CARs in lieu of BHARs in roughly $4 \%$ of all sampling situations. Second, even if the inference based on cumulative abnormal returns is correct, the documented magnitude does not correspond to the value of investing in the average or median sample firm relative to an appropriate benchmark over the horizon of interest. Yet this is precisely the objective of long-run event studies of stock returns.

In addition, we document that there are significant biases in test statistics when long-run abnormal returns are calculated using a reference portfolio (such as a market index). We identify three reasons for the bias in test statistics based on abnormal returns calculated in this manner - the new listing bias, the rebalancing bias, and the skewness bias. Cumulative abnormal returns are most affected by the new listing bias. As a result, long-run cumulative abnormal returns and the associated test statistics are generally positively biased. In contrast, long-run buyand-hold abnormal returns are more affected by the rebalancing and skewness biases. As a result, long-run buy-and-hold abnormal returns and the associated test statistics are generally negatively biased. Though these reference portfolio approaches are the most commonly used methods in financial economics, our results and those of Kothari and Warner (1996) highlight the problems associated with calculating long-run abnormal returns using either a reference portfolio or an asset pricing model.

Finally, and perhaps most importantly, we identify a method of measuring long-run abnormal returns that yields well-specified test statistics. We document that matching sample firms to control firms of similar size and book-to-market ratios yield well-specified test statistics in virtually all sampling situations that we consider. By matching sample firms to control firms on specified firm characteristics, we are able to alleviate the new listing bias (since both sample and control firms must be listed in the identified event month), the rebalancing bias (since the returns of the sample and control firms are compounded in an analogous fashion), and the skewness bias (since abnormal returns calculated using this control firm approach are reasonably symmetric). Matching on firm size and book-to-market ratio works well in random samples and samples with size-based or book-to-market based sampling biases. However, as future research in financial economics discovers additional variables that explain the cross-sectional variation 
in common stock returns, it will also be important to consider these additional variables when matching sample firms to control firms.

\section{References}

Agrawal, Anup and Jeffrey F. Jaffe, 1996, The pre-acquisition performance of target firms: A reexamination of the inefficient management hypothesis, Working paper (Wharton School, University of Pennsylvania, Philadelphia, PA).

Agrawal, Anup, Jeffrey F. Jaffe, and Gershon Mandelker, 1992, The post-merger performance of acquiring firms in acquisitions: A re-examination of an anomaly, Joumal of Finance 47, $1605-1621$.

Asquith, Paul and Lisa Muelbroek, 1996, An empirical investigation of short interest, Working paper (Harvard Business School, Cambridge, MA).

Ball, Ray, S.P. Kothari, and Charles E. Wasley, 1995, Can we implement research on stock trading rules?, Journal of Portfolio Management 21, 54-63.

Barber, Brad M. and John D. Lyon, 1996a, How can long-run abnormal stock returns be both positively and negatively biased?. Working paper (University of California, Davis, CA).

Barber, Brad M. and John D. Lyon, 1996b, Firm size, book-to-market ratio, and security returns: A holdout sample of financial firms, Journal of Finance, forthcoming.

Bernard, Victor and J. Thomas, 1989, Post-earnings-announcement drift: Delayed price response or risk premium?, Journal of Accounting Research, Supplement, 1-36.

Blume. Marshall E. and Robert F. Stambaugh, 1983, Biases in computed returns: An application to the size effect, Journal of Financial Economics 12, 387-404.

Brav, Alon and Paul A. Gompers, 1995, Myth or reality? The long-run underperformance of initial public offerings: Evidence from venture and nonventure capital-backed companies, Working paper (Harvard Business School, Cambridge, MA).

Brav, Alon, Christopher Geczy, and Paul A. Gompers, 1995. The long-run underperformance of seasoned equity offerings revisited, Working paper (Harvard Business School, Cambridge, MA).

Brown, Stephen J. and Peter F. Pope, 1996, Post-earnings announcement drift?, Working paper (New York University. New York, NY).

Brown, Stephen J. and Jerold B. Warner, 1980, Measuring security price performance, Journal of Financial Economics 8, 205-258.

Brown, Stephen J. and Jerold B. Warner, 1985, Using daily stock returns: The case of event studies, Journal of Financial Economics 14, 205--258.

Campbell, Cynthia J. and Charles E. Wasley, 1993, Measuring security price performance using daily NASDAQ returns, Journal of Financial Economics 33, 73-92.

Canina, Linda, Roni Michaely, Richard Thaler, and Kent Womack, 1996, A warning about using the daily CRSP equally-weighted index to compute long-run excess returns, Journal of Finance, fortheoming.

Chan, Louis K.C., Narasimhin Jegadeesh, and Josef Lakonishok, 1995, Evaluating the performance of value versus glamour stocks: The impact of selection bias, Journal of Financial Economics 38 , $269-296$.

Conrad, Jennifer and Gautum Kaul, 1993, Long-term market overreaction or biases in computed returns?, Journal of Finance 48, 39-64.

Davis, James L., 1994, The cross-section of realized stock returns: The pre-Compustat evidence, Journal of Finance 49, 1579-1593.

Desai. Hemang and Prem C. Jain, 1995, An analysis of the recommendations of the 'superstar' money managers at Barron's annual roundtable, Joumal of Finance 50, 1257-1274.

Desai, Hemang and Prem C. Jain, 1996, Long-run common stock returns following stock splits and stock dividends, Working paper (Tulane University, New Orleans. LA). 
Dharan, Bala G. and David lkenberry, 1995, The long-run negative drift of post-listing stock returns, Journal of Finance 50, 1547-1574.

Dimson. Elroy and Paul Marsh, 1986, Event study methodologies and the size effect, Journal of Financial Economics 17, 113-142

Dyckman. Thomas, Donna Philbrick, Jens Stephan, and William E. Ricks, 1984, A comparison of cvent study methodologies using daily stock returns: A simulation approach. Journal of Accounting Research 22, 1-33.

Fama, Eugene F. and Kenneth French, 1992, The cross-section of expected stock returns, Journal of Finance $47,427-466$.

Fama. Eugene F. and Kenneth French, 1993. Common risk factors in returns on stocks and bonds, Journal of Financial Economics 33, 3-56.

Field, Laura Casares, 1996, Is institutional investment in initial public offerings related to long-run performance of these firms?, Working paper (University of California, Los Angeles, CA).

Gompers, Paul and Josh Lerner, 1995, Venture capital distributions: short-run and long-run reactions, Working paper (Harvard Business School, Cambridge, MA).

Hall, Peter, 1992, On the removal of skewness by transformation, Journal of the Royal Statistical Society B 54, 221-228.

Hollander, Myles and Douglas A. Wolfe, 1973. Nonparametric statistical methods (Wiley, New York, NY).

Ikenberry, David, Josef Lakonishok, and Theo Vermaelen, 1995, Market underreaction to open market share repurchases, Journal of Financial Economics 39, 181-208.

Ikenberry, David, Graeme Rankine, and Earl K. Stice. 1996, What do stock splits really signal?, Journal of Financial and Quantitative Analysis 31, 357--375.

Kothari, S.P. and Jerold B. Warner, 1996. Measuring long-horizon security price performance, Journal of Financial Economics, this issue.

Kothari, S.P., Jay Shanken, and Richard G. Sloan. 1995. Another look at the cross-section of expected stock returns, Journal of Finance $50,185 \cdot 224$.

Lee, Inmoo, 1995, Do firms knowingly sell overvalued equity?, Working paper (University of lllinois, Urbana, IL.).

Loughran, Tim and Jay Ritter, 1995. The new issues puzzle, Journal of Finance 50. 23-52

Loughran. Tim and Jay Ritter, 1996, Long-term market overreaction: The effect of low-priced stocks, Journal of Finance, forthcoming.

Michaely, Roni and Kent Womack, 1996. Confliet of interest and the credibility of underwriter analyst recommendations, Working paper (Cornell University, Ithaca, NY).

Michaely, Roni, Richard H. Thaler, and Kent L. Womack. 1995, Price reactions to dividend initiations and omissions: Overreaction or drift?. Journal of Finance $50.573 \cdots 608$.

Rau, P. Raghavendra and Theo Vermaelen. 1996. Glamour, value and the post-acquisition performance of acquiring firms, Working paper (INSEAD. Fountainebleau Cedex).

Ritter. Jay R.. 1991, The long-run performance of initial public offerings, Journal of Finance 46 , $3-27$.

Roll, Richard. 1983, On computing mean returns and the small firm premium, Journal of Financial Economics 12, 371-386.

Spiess, D. Katherine and John Affleck-Graves. 1995. Underperformance in long-run stock returns following seasoned equity offerings, Journal of Financial Economics 38, 243-268.

Spiess, D. Katherine and John Affleck-Graves. 1996. The long-run performance of stock returns following debt offers, Working paper (University of Notre Dame, South Bend, IN).

Teoh. Siew Hong, Ivo Welch, and T.J. Wong, 1995. Earnings management in seasoned equity offerings, Working paper (University of Michigan. Ann Arbor, Ml).

Womack, Kent L., 1996, Do brokerage analysts' recommendations have investment value?. Journal of Finance 51. 137-168. 